This is an Accepted Manuscript of an article published by Cambridge University Press in the Journal of the Society for American Music on 30 September 2014, available online http://journals.cambridge.org/action/displayAbstract?fromPage=online\&aid=9355426\&fullte $\underline{\text { xtType}=\mathrm{RA} \& \text { fileId }=\mathrm{S} 1752196314000236}$.

Catherine Haworth, "Something beneath the flesh": music, gender, and medical discourse in the 1940s female gothic film', Journal of the Society for American Music, 8/3, August 2014, 338-370.

DOI: http://dx.doi.org/10.1017/S1752196314000236.

Copyright (C) The Society for American Music 2014.

\title{
"Something beneath the flesh": Music, Gender, and Medical Discourse in the 1940s Female Gothic Film
}

\section{CATHERINE HAWORTH}

\begin{abstract}
Closely related to both film noir and the woman's film, 1940s female gothic pictures combine suspense and mystery with a focus on the subjective experience of the female protagonist. This article discusses the use of music and sound in the cinematic female gothic tradition, focusing upon two historically located films that form part of its "gaslight" subgenre: Experiment Perilous (dir. Tourneur; comp. Webb, 1944) and The Spiral Staircase (dir. Siodmak; comp. Webb, 1946). In both films, the positioning of the female lead is mediated by the presence of a medical discourse revolving around her professional and romantic relationship with a male doctor, whose knowledge and authority also allows him to function as an unofficial investigator into the woman's persecution at the hands of a serial murderer. The female gothic soundtrack is a crucial
\end{abstract}

\footnotetext{
I am grateful to David Cooper, Rachel Cowgill, and Annette Davison, as well as the journal's anonymous reviewers, for their valuable comments on earlier versions of this essay.
} 
element in the creation and communication of this gendered discourse, articulating the shifting position of characters in relation to issues of crime, criminality, and romance. Musical and vocal control reinforce the doctor's dominance whilst allying his presentation with that of an emasculated killer, and create and contain agency within complex constructions of female victimhood.

With its strong emphasis on subjectivity, intimations of the supernatural, and foregrounding of female experience, the female gothic literary tradition inspired numerous 1940s Hollywood films focused on women under threat from men known personally to them. ${ }^{1}$ Like the domestic and emotional dramas that characterized the broader category of the woman's film, the female gothic narrative was thought to appeal strongly to women, a particularly important audience for Hollywood during World War II. ${ }^{2}$ With its heroines frequently fulfilling an explicitly investigative role, the female gothic was suspenseful hybrid of horror, crime, mystery, and the woman's film: a combination that perhaps explains its tendency to be subsumed within critical discussion of these more neatly coherent, distinct, or prestigious categories. Examining these films as a discrete style or genre of 1940s cinema reveals the significance of their approach to paranoia, suspense, and characterization — and the role of the soundtrack in constructing the shifting and subjective experience of the female gothic

\footnotetext{
${ }^{1}$ Various subgenres and recurring themes or motifs within this relatively broad definition of the female gothic genre have also been identified, although primarily by scholars focused upon literary texts. An overview of these developments is provided in Andrew Smith and Diana Wallace, "The Female Gothic: Then and Now," Gothic Studies 6/1 (2004): 1-7. The historically located "gaslight" films discussed below are an example of one such subset within the cinematic female gothic tradition.

${ }^{2}$ Tania Modleski, Loving with a Vengeance: Mass-Produced Fantasies for Women, 2nd ed. (New York: Routledge, 2008), 10-12.
} 
heroine. ${ }^{3}$ Music and sound thus not only play a vital role in articulating the genre's distinguishing features, but also have wider implications for our understanding of issues of gender, subjectivity, and agency within the classical Hollywood scoring tradition. ${ }^{4}$

The two films explored in detail here, Experiment Perilous (1944) and The Spiral Staircase (1946), locate elements of the female gothic genre within a turn-of-the-century setting that identifies them as what Guy Barefoot describes as "gaslight melodramas": creepy historical whodunits popular with U.S. and British studios from the late 1930s to early 1950s. These films exploited the motif of flickering gaslight to establish period settings via Expressionist lighting, create shadowy narratives full of suspense, and thematicize the

\footnotetext{
${ }^{3}$ Helen Hanson, "From Suspicion (1941) to Deceived (1991): Gothic Continuities, Feminism and Postfeminism in the Neo-Gothic Film," Gothic Studies 9/2 (2007): 20-32; Steve Neale, Genre and Hollywood (London: Routledge, 2000), 163-64. There are notable exceptions to this relative neglect, but they are often films that have attracted attention as texts associated with particular filmmaking personnel or star performances (for example, Alfred Hitchcock directing Joan Fontaine in Rebecca [1940] and Suspicion [1941]), or where
} discussion has focused on these films' position within another, more extensively theorized tradition (horror, the woman's film, film noir), rather than on the female gothic itself as a distinct genre or cycle.

${ }^{4}$ As with these films more widely, the female gothic soundtrack has received relatively little attention, though there are important overlaps here with work on related genres, films, and traditions. See Isabella van Elferen, Gothic Music: The Sounds of the Uncanny (Cardiff: University of Wales Press, 2012); Peter Franklin, Seeing Through Music: Gender and Modernism in Classic Hollywood Film Scores (Oxford: Oxford University Press, 2011); Helen Hanson, Hollywood Heroines: Women in Film Noir and the Female Gothic Film (London: I. B. Tauris, 2007); and Heather Laing, The Gendered Score: Music in 1940s Melodrama and the Woman's Film (Aldershot: Ashgate, 2007). David Neumeyer and Nathan Platte's Film Score Guide to Franz Waxman's music for Rebecca identifies the film as an important milestone in Hollywood's development of the female gothic narrative, noting that the "varied and dramatic character" and "highly distinctive themes" associated with female characters shaped the overall shape and sound of this developing genre. David Neumeyer and Nathan Platte, Franz Waxman's Rebecca: A Film Score Guide (Lanham, MD: Scarecrow Press, 2012), 145. 
subjective experience of their confused and disoriented female protagonists. ${ }^{5}$ Both films focus on a central heroine who is the intended victim of a deranged serial killer-a persecutor who, as is common in the female gothic, is already known to her. The reasons behind the woman's victimization (and the killer's mental instability) are also the subject of a medical discourse that runs throughout the narrative. This discourse is introduced and curated by a male doctor, who becomes intimately involved in the woman's dual quest for safety and romantic fulfillment and also provides a model of masculinity that highlights the murderer's comparative feminization.

Both Experiment Perilous and The Spiral Staircase are therefore typical of the female gothic genre, which represents gendered and sexual identity in complex and contradictory ways - representational practices that are here additionally codified and communicated through the presence of medical discourse (discussed in further detail below). Female gothic films place women at the heart of the story, stressing their experience in a way that challenges the male-centricity of much classical cinema. However, they also focus upon the victimization of these heroines, who, despite occasional forays into the active and agent role of detective, are generally reliant on men for rescue, or who are sometimes even revealed to

\footnotetext{
${ }^{5}$ The archetypal gaslight film was MGM's popular 1944 adaptation of Patrick Hamilton's stage play Gas Light (following an earlier adaptation released by Anglo-American in 1940). Released as Gaslight, the film starred Ingrid Bergman as a woman whose husband tries to convince her she is insane as a means of disguising his search for her family fortune. Variations on this plotline, in which a victim is gradually manipulated to doubt their own sanity, spawned several cinematic imitators—including Experiment Perilous—and gave rise to the term "gaslighting" to describe this kind of psychological abuse. Somewhat confusingly, not all gaslight films contained gaslighting plots, though they shared a common emphasis on the subjective and suspenseful. See Guy Barefoot, Gaslight Melodrama: From Victorian London to 1940s Hollywood (New York: Continuum, 2001), 116; and Patrick Hamilton, Gas Light: A Victorian Thriller in Three Acts (London: Constable, 1939). For discussion of several gaslighting plots, see Marlisa Santos, The Dark Mirror: Psychiatry and Film Noir (Lanham, MD: Lexington Books, 2011), 139-63.
} 
have imagined their persecution after all. These narrative elements are highlighted and extended in the films' use of music and sound to perform a variety of practical and political functions: drawing together the romantic and criminal elements of the plot, underlining the medicalized authority of the doctor over both the victim and the murderer, valorizing his particular brand of masculinity, and ensuring that the emotional threat of female agency and the physical menace of the killer are contained.

Despite these cohesive and identifiable elements of plot, characterization, and style, the terminology used to describe female gothic films during the 1940s varied quite widely. However, their most common description in trade publications was as "melodrama"-a term used to describe practically any non-comic genre that focused on action, tension, and suspense. ${ }^{6}$ The New York Times, for example, described Experiment Perilous as "one of the better psychological melodramas," and noted that the "creepy melodrama" of The Spiral Staircase made it "a shocker, plain and simple."7 These films were also marketed as

\footnotetext{
${ }^{6}$ Steve Neale, "Melo Talk: On the Meaning and the Use of the Term 'Melodrama' in the American Trade Press," Velvet Light Trap 32 (1993): 66-89. This variation in terminology is also a feature of more recent scholarship on the female gothic, whose films are described as "gothic romance films" by Diane Waldman; “victim films” by Thomas Leitch; “paranoid woman’s films” by Mary Ann Doane and Mark Jancovich; and “noir women's films” by Andrea Walsh. See Mary Ann Doane, The Desire to Desire: The Woman's Film of the 1940s (Bloomington: Indiana University Press, 1987), 38-69; Mark Jancovich, “Crack-Up: Psychological Realism, Generic Transformation and the Demise of the Paranoid Woman's Film," Irish Journal of Gothic and Horror Studies 3 (2007), http://irishgothichorrorjournal.homestead.com/Crack-upJancovich.html; Thomas Leitch, Crime Films (New York: Cambridge University Press, 2002), 80; Diane Waldman, ““At Last I Can Tell It to Someone!': Feminine Point of View and Subjectivity in the Gothic Romance Film of the 1940s," Cinema Journal 23/2 (1984): 29-40; and Andrea S. Walsh, Women's Film and Female Experience 1940-1950 (New York: Praeger, 1984), 170.

${ }^{7}$ Bosley Crowther, “The Spiral Staircase,” New York Times, 7 February 1946; T. M. P., “At the Palace,” New York Times, 30 December 1944.
} 
particularly "highbrow" thrillers: a logical approach that aimed to capitalize on the female gothic's "intellectual" emphasis on the psychological, in combination with the lavishly recreated historical settings of the gaslight cycle. Again, this approach has been linked to Hollywood's desire to appeal specifically to women: Tim Snelson describes the advertising of The Spiral Staircase as a clear example of the "prestige horror" approach to 1940s melodrama, challenging the oft-held assumption that horror films were addressed to a predominantly male audience. $^{8}$

This multiplicity of generic influences is apparent in elements of the female gothic film's construction and characterization, as well as its marketing and reception. Female gothic narratives typically combine the focus on feminine experience that typifies the woman's film, with stock devices from the horror genre and an emphasis on crime, mystery, and subjectivity that is more commonly associated with film noir-a style of filmmaking noted for its preoccupation with the shifting gendered roles and identities that characterized 1940s American society. The emasculated antiheroes, war-damaged veterans, and femmes fatales that populate film noir have been theorized as representing the threats to traditional masculinities posed by conscription and active combat, the rise in female blue and whitecollar workers, and the increasing diversity of the family unit. ${ }^{9}$ The female gothic film can be understood as offering a specifically "feminine" perspective on these issues; the intimidating houses where the heroine's persecution frequently takes place function as a kind of prison, and have been linked with anxieties about the societal demands and expectations placed upon

\footnotetext{
${ }^{8}$ Tim Snelson, ““From Grade B Thrillers to Deluxe Chillers’: Prestige Horror, Female Audiences, and Allegories of Spectatorship in The Spiral Staircase (1946)," New Review of Film and Television Studies 7/2 (2009): 173-88. See Guy Barefoot, Gaslight Melodrama, 140-44.

${ }^{9}$ Helen Hanson, Hollywood Heroines, 11-32; Frank Krutnik, In a Lonely Street: Film Noir, Genre, Masculinity (London: Routledge, 1991), 75-91; James Naremore, More Than Night: Film Noir in Its Contexts (Berkeley: University of California Press, 1998).
} 
women in occupying domestic and professional roles in the years around World War II. ${ }^{10}$ More positively, the active participation of the female gothic heroine in investigating the threat posed to her safety can (temporarily) reposition her into the authoritative role of detective, a defiant shift in characterization that may well have resonated with female audiences of the time. ${ }^{11}$ Even in those films that eschew a focus on women as investigators, the centrality of the heroine's subjectivity to our experience of the narrative can create unusually powerful and enduring depictions of classical Hollywood femininity.

As relatively typical female gothic films of the mid-1940s, Experiment Perilous and The Spiral Staircase therefore sit at the intersection of two of Hollywood's evolving approaches to the crime narrative. Their historical settings, high production values, and emphasis on thrills and suspense recall the prestige melodramas produced earlier in the decade, whilst the heavy emphasis on psychological realism within both the victim and serial killer storylines points towards the grittier and heavily intellectualized hardboiled style that became increasingly popular as the genre progressed. ${ }^{12}$ The centrality of their female leads to both of these strands demonstrates the pivotal role played by women in the female gothic narrative: not only as active and engaging heroines who far exceed their "passive victim"

\footnotetext{
${ }^{10}$ Janet Walker notes the conflicting pressures placed on American women in the postwar years; they were expected to conform to the idealized roles of wife, mother, and homemaker, yet continued to play an increasingly important role in the workforce (where they were often made to feel guilty about taking "men's jobs" even though their employment conditions were much worse). Janet Walker, "Hollywood, Freud and the Representation of Women: Regulation and Contradiction, 1945-Early 1960s," in Home Is Where the Heart Is: Studies in Melodrama and the Woman's Film, ed. Christine Gledhill (London: British Film Institute, 1987), 197-214. See also Tania Modleski, Loving with a Vengeance, 11-12; and Diane Waldman, “'At Last I Can Tell It to Someone."”

${ }^{11}$ Helen Hanson, Hollywood Heroines, 53-54.

${ }^{12}$ Mark Jancovich, "Crack-Up.”
} 
stereotype, but also as a key audience for the motion picture industry.

\section{Diagnosis Murder: Medical Discourse And The Doctor-Detective}

The unusual level of agency and textual control found in many female gothic heroines represents a clear threat to the patriarchal depiction of identity more commonly found in classical film, and care is often taken to cast doubt upon the reliability of the heroine's vision and understanding. Mary Ann Doane argues that the female gothic film provides one of the most overt examples of Hollywood's objectification of women: the female lead's credibility as a witness is constantly undercut by other characters and the narrative structure of the film itself, containing the threat of active female investigation by emphasizing the heroine's construction as a persecuted and powerless victim, paranoid and hysterical fantasist, or a combination of the two. ${ }^{13}$ These strategies of containment are clearly evident in Experiment Perilous and The Spiral Staircase; despite the characterization of Allida and Helen as charming, romantic heroines, they are explicitly positioned as victims who require rescue, and whose reliability and stability is further drawn into question through the continual questioning of their health. This medical discourse constructs mental and physical illness as particularly feminine afflictions, a gendered diagnosis that is applied not just to the heroine, but also to the unhinged and effeminized man who is persecuting her.

The presence of medical discourse in classical-era Hollywood cinema has been most frequently documented within the generic confines of the woman's film, although narrative strands that deal with elements of physical or mental health are relatively common throughout the forties, and are particularly important in film noir. ${ }^{14}$ Doane argues that the male doctor/female patient relationship is a recurring and heavily eroticized feature that

\footnotetext{
${ }^{13}$ Doane, The Desire to Desire, 123-54.

${ }^{14}$ Frank Krutnik, In a Lonely Street, 45-55; and Marlisa Santos, The Dark Mirror, xi-xvi.
} 
serves to "narrativize" the usually unknowable woman, and to merge her quests for health and romantic happiness into one search for a cure that almost invariably the handsome and authoritative doctor is able to provide. ${ }^{15}$ The physical and mental sites of illness are often collapsed together in these storylines; regardless of the patient's original symptoms, her whole being (including her personality and morals) is implicated in the diagnosis, effects, and treatment of disease. This allows films invoking medical discourse to give the illusion of engaging more deeply with the inner fears, desires, and motivations of female characters than is commonly held to be the case in classical cinema-something that Cissie, in Experiment Perilous, describes as the doctor's ability to see "beneath the flesh" - and that was presumably held to be an important part of the intended appeal of these films to female viewers. $^{16}$

As the primary explorer of this uncharted feminine terrain, the doctor acts as a guide for the audience, and his privileged access to the patient and those around her (which in the female gothic film necessarily also includes her persecutor) means that he has a high degree of narrative agency — an agency and authority that straddles and elides, often problematically, the criminal and romance strands of the story. The aura of mystique around the physician (and especially around the psychiatrist) is significant in allowing characters who are often bookish and scholarly to assume the privileged position of hero: despite his comparative lack of conventionally tough physical markers, the doctor's medical knowledge grants him a

\footnotetext{
${ }^{15}$ Mary Ann Doane, “The Clinical Eye: Medical Discourses in the 'Woman's Film' of the 1940s," Poetics Today 6/1-2 (1985): 205-27; Doane, The Desire to Desire, 38-69. There are also examples of medical narratives that feature female doctors and psychiatrists, but these often make a feature of perceived conflict between professional and personal identities — suggesting that whilst women may make excellent doctors or desirable wives, they can rarely achieve both at once. Krin Gabbard and Glen O. Gabbard, Psychiatry and the Cinema (Chicago: University of Chicago Press, 1987), 21-29.

${ }^{16}$ Walsh, Women's Film, 167-76.
} 
deeper understanding of human nature (and especially of femininity) that constructs him as both professionally competent and desirable. His control over the diagnosis and treatment of disease not only gives the doctor power over the patient and their family, but also frequently enables him to influence the police and other institutions. In female gothic films, where much can turn on the question of the heroine's sanity and the credibility of her perceived persecution, the doctor's relationship with the female patient can have particularly farreaching consequences.

Medical discourse in 1940s cinema is most commonly and extensively articulated using the language and techniques associated with Freudian psychoanalysis, reflecting the general popularization of these ideas in American society during the decade. ${ }^{17}$ This preoccupation with psychology and psychoanalysis means that mental, rather than physical, illness is the most common subject of studio-era medical discourse - a frequently sexualized psychoanalytic focus that, together with the gendered hierarchy that is often in place between doctor and patient, has most commonly been understood as acting primarily to reinforce misogynist presentations of women as weak, subordinate, and overemotional. Associations between femininity and the irrational also underpin the appearance of "gaslighting" itself, a form of medical discourse which intersects directly with the persecution narratives at the center of the female gothic - as is the case in Experiment Perilous, where the heroine's unhinged husband manipulates their home environment to disorient his wife, and feeds their young son stories about his mother's frightening and unstable nature.

Although gaslighting stories, and related mental health plots within the female gothic genre, do not exclusively focus upon male aggressors and female victims, this is by far their

\footnotetext{
${ }^{17}$ Michael Shortland, "Screen Memories: Towards a History of Psychiatry and Psychoanalysis in the Movies," The British Journal for the History of Science 20/4 (1987): 421-52; Walker, "Hollywood, Freud and the Representation of Women."
} 
most common incarnation. Despite the heroine's ultimate sanity, her perception of reality is often portrayed as being peculiarly fragile or susceptible to manipulation, pathologizing the feminine in a way that can also be used to characterize the man persecuting her. While many villains are motivated by purely practical concerns (wishing to cover up a crime, steal an inheritance, or marry someone else), there are also several films where their actions are portrayed as resulting from a form of psychosis - a twist on what is essentially a serial killer storyline. This brings the reliance of these films on medical discourse full circle, using the links between femininity and madness to emasculate the villain in ways that recall the bookish intellectualism of the doctor - though here without the easy bedside manner and professional authority that ensure the physician's attractive manliness. This approach distinguishes the disturbed criminal or serial killer from other representations of male psychosis during the 1940s, which most commonly focus on the figure of the traumatized but heroic War veteran, or upon temporary mental distress that the romantic attentions of a woman can alleviate.

Although the historical and domestic setting of gaslight's take on the female gothic film differentiates it from the hardboiled urban narratives most commonly associated with 1940s crime cinema, it is still possible to read its depictions of gender against the decade's backdrop of societal flux. The bookish doctor provides a hero whose authority can be specifically tied to the popularization of psychoanalysis, whilst the potential dangers of this education in the wrong hands are represented by the similarly erudite, but unstable and effeminized, psychopathic killer. That both of these non-normative constructions of masculinity are still able to hold sway over women who are most commonly portrayed as a combination of the persecuted victim, helpless romantic, and feeble patient demonstrates the enduring potency of Hollywood's vision of dependent and subordinate femininity. 


\section{Gender And Subjectivity In The Female Gothic Soundtrack}

The 1940s were the height of what has come to be known as the "classical" style of Hollywood film scoring: extensive and expansive orchestral scores in the late Romantic style that, at least at a surface level, engage with markers of mood, tone, and characterization in relatively congruent ways that rely heavily on the leitmotif system. ${ }^{18}$ Although female gothic scores fit broadly into these stylistic models, closer examination reveals a complex relationship between the soundtrack and character subjectivity plays a crucial role in articulating the genre's gendered medical hierarchies. In conjunction with subjectivity and narrative "ownership," the soundtrack also facilitates navigation of the structural devices associated with the doctor-patient relationship and the "talking cure," using flashbacks, dream sequences, and voiceover narration to dramatize the revelations of the analysand or the insights of the psychoanalyst. Music and sound therefore mirror the female gothic's broader cross-genericism, combining the suspense and ambiguity of the typical noir soundtrack with the musical emphasis of emotion and "femininity" that are commonly associated with the woman's film. ${ }^{19}$

As in the majority of classical scores, the female gothic soundtrack defines femininity primarily as sonic "excess" and thereby sonic difference. As James Buhler summarizes, the overly close relationship often posited between female characters (especially when shot in lingering close up) and the soundtrack most commonly functions as a "burden" of signification: a burden of irrational, connotative emotion, rather than agent action or spoken,

\footnotetext{
${ }^{18}$ Models of classical scoring practices largely continue to follow those outlined in Claudia Gorbman, Unheard Melodies: Narrative Film Music (London: BFI Publishing, 1987).

${ }^{19}$ Helen Hanson, “The Ambience of Film Noir: Soundscapes, Design, and Mood,” in A Companion to Film Noir, ed. Andrew Spicer and Helen Hanson (Chichester: John Wiley and Sons, 2013), 285-301; Heather Laing,
} The Gendered Score; Richard R. Ness, “A Lotta Night Music: The Sound of Film Noir,” Cinema Journal 47/2 (2008): 52-73. 
concrete meaning; and of a need to supplement the image of woman with music that purports to tell us what she is feeling, and thereby what, or who, she is. ${ }^{20}$ This interiorizing conception of femininity as all emotion, and perhaps little substance is commonplace amongst Hollywood's good wives and girlfriends, and positions them in romantic and romanticizing ways - thereby making it very easy to define them primarily through their relationship with, or attractiveness to, the film's male characters. ${ }^{21}$ Therefore, despite their construction around and about female characters, these musical cues most commonly function as signifiers of masculine narrative agency, defining womanhood in terms of its desirability, "possessability," and difference. As the case studies below demonstrate, it is primarily male characters who "own" and motivate this feminized musical material. Such music indicates male subjectivity, evoking the sonic presence of the woman without necessarily accounting for her experience. Moments where "her music" is prominent are often when female subjugation and containment are at their height.

Both Peter Franklin and Robynn Stilwell identify a similar containment of female agency in their respective work on classical scoring and more contemporary film. Franklin argues that Hollywood's use of a late Romantic musical idiom at a time when "serious" composition was driven and evaluated by modernist principles can result in the feminization of the film score itself, which makes its engagement with female characters particularly

\footnotetext{
${ }^{20}$ James Buhler, "Gender, Sexuality, and the Soundtrack," in The Oxford Handbook of Film Music Studies, ed. David Neumeyer (Oxford: Oxford University Press, 2014), 366-382. Buhler's discussion here draws closely upon Mary Ann Doane, "Ideology and the Practice of Sound Editing and Mixing," in The Cinematic Apparatus, ed. Teresa de Lauretis and Stephen Heath (Milwaukee, WI: MacMillan, 1980), 47-56; and Heather Laing, The Gendered Score.

${ }^{21}$ Although typically featuring very different musical signifiers, there are similarities in approach here with the markers of "otherness" that often characterize the femme fatale.
} 
significant. ${ }^{22}$ The association of women with music and musicality often threatens the masculine autonomy of the hero and is usually summarily dealt with; either through the silencing of women's music, or through the use of its popular and passionate styling to suggest their fragility and lack of emotional control. Stilwell's discussion of more recent soundtracks identifies a similar relationship between femininity and overemotionalism, where subjective uses of cinematic sound and vision are divided along gendered lines. ${ }^{23}$ Whilst male characters are most frequently associated with control of the camera, the use of subjective sound is commonly reserved for women, where it emphasizes fear, stress, or volatility. The soundtrack therefore reinforces the cultural connections between femininity and irrationality (a relationship which is particularly significant in the female gothic's use of medical discourse). Stilwell's concept of “subjective sound" sits closely alongside Claudia Gorbman's definition of "metadiegetic" scoring - musical narration occurring when we "are privileged to read [a character's] thoughts." ${ }^{24}$ As the use of "privilege" here indicates, metadiegetic cues

\footnotetext{
${ }^{22}$ Peter Franklin, Seeing through Music.

${ }^{23}$ Robynn Stilwell, "Sound and Empathy: Subjectivity, Gender and the Cinematic Soundscape," in Film Music:
}

Critical Approaches, ed. Kevin Donnelly (New York: Continuum, 2001), 167-87.

${ }^{24}$ Claudia Gorbman, Unheard Melodies, 23. The definition and categorization of film sound's relationship with the diegesis is an area of ongoing discussion. Here, I will rely on the broad categories of "nondiegetic" music as that audible only to the cinema audience, "diegetic" as audible to both characters and audience, and "subjective" to describe those moments when the soundtrack gives a particularly clear indication of a character's interior thoughts, responses, or recollections. For an outline of recent debate in this area, see Ben Winters, "The Nondiegetic Fallacy: Film, Music, and Narrative Space,” Music \& Letters 91/2 (2010): 224-44. Isabella van Elferen notes that "gothic" film scores (chronologically and stylistically a much broader notion than the female gothic considered here, but one with some overlaps - especially in the centrality of "horror" tropes to the scoring of intertwined subjectivity, suspense, and emotional excess) are frequently characterized by transgressive moves into the "twilight zone" around the boundaries of diegetic, nondiegetic, and metadiegetic sound. Isabella van Elferen, Gothic Music, 70-72. 
can offer a powerful connection with subjectivity, but as Stilwell points out, this insight can work to limit as well as highlight character agency. The films examined here make particularly frequent use of subjective sound and music relating to both men and women, articulating and extending male control of the narrative, often directly at the expense of female agency. Although not necessarily conforming to the gendered model of sonic subjectivity that Stilwell proposes, they therefore provide ample support for her overall conclusions.

One of the most notable ways in which sound is used to highlight gendered cinematic subjectivities is that of voiceover narration - a powerful and authoritative device that provides one of the strongest indications of character experience and is overwhelmingly associated with men. ${ }^{25}$ Even in genres such as film noir, where voiceover commonly appears as a means of telling the story of the traumatized fall-guy antihero, the centrality and immediacy of the narrator's experience ensures he retains authority over the text. ${ }^{26}$ In comparison, films featuring female voiceover tend to heavily mediate the usual authority of the narrator-author figure. They often stress the subordinate role of women in the stories they tell (for example, the domestic and romantic tropes that underpin typical epistolary voiceovers), ${ }^{27}$ or bury female narration within a more immediate and obvious masculine

\footnotetext{
${ }^{25}$ Sarah Kozloff, Invisible Storytellers: Voice-over Narration in American Fiction Film (Berkeley: University of California Press, 1988).

${ }^{26}$ Kaja Silverman, The Acoustic Mirror: The Female Voice in Psychoanalysis and Cinema (Bloomington: Indiana University Press, 1988).

${ }^{27}$ Heather Laing, The Gendered Score, 75-77; Kaja Silverman, The Acoustic Mirror, 57-58.
} 
discourse (for example, the doctor's authority over the female analysand's story, or the positioning of female voiceover as a contribution to a male-narrated story). ${ }^{28}$

The female gothic soundtrack therefore makes clear the frequently problematic and hierarchical construction of gender that permeates the cycle, and is highly significant in facilitating or withholding our access to character experience and subjectivity. In a genre defined by mystery and questions about the veracity of knowledge and human fallibility, it plays a particularly crucial role. The scores of both Experiment Perilous and The Spiral Staircase are credited to senior RKO Radio Pictures house composer Roy Webb, who worked at the studio from the late 1920s through to its demise under Howard Hughes in the midfifties. Although mentioned somewhat infrequently in film music literature, Webb is particularly noted for his film noir and horror scores, where his comparatively complex harmonic language and subtle, understated approach to classical scoring complement and extend the tension and ambiguity that characterize these genres. ${ }^{29}$ Webb's music for Experiment Perilous and The Spiral Staircase combines sparse and suspenseful scoring with more conventionally expansive themes designed to highlight the romantic aspects of the female gothic narrative, but the ways in which these cues engage with medicalized issues of

\footnotetext{
${ }^{28}$ An approach demonstrated particularly clearly in The Locket (1946), where leading lady Nancy’s narration and flashback take place at the third level of the film's nested flashbacks (her story is part of Clyde's, which is itself an episode within Blair's flashback sequence).

${ }^{29}$ Although still largely conforming to the stylistic and structural conventions associated with the "classical style," Webb's music is generally more low key and less obviously melodically driven than, for example, Max Steiner's (often described as the epitome of 1940s Hollywood music practice). There is much yet to be said about Webb's contribution to (and extension of) the classical Hollywood scoring tradition, but this is beyond the scope of the analyses presented here. Randall D. Larson, "The Quiet Horror Music of Roy Webb: Scoring Val Lewton (the Jacques Tourneur Films)," Midnight Marquee 40 (1990): 14-17; Christopher Palmer, The Composer in Hollywood (London: Marion Boyars, 1990), 160-83.
} 
control, subjectivity, and identity reveal the misogynist processes at the heart of these supposedly female-centered stories. Both films also rely heavily on the use or absence of voice to communicate these ideas: the heroine of The Spiral Staircase is literally silenced by a psychological trauma that renders her physically mute, and Experiment Perilous makes the doctor's authority clear in its use of voiceover narration.

\section{"If I Were Painting Her I'd Do Her Quite Differently"-Perception, Control, And The}

\section{Doctor-Detective In Experiment Perilous}

Set in the early 1900s, Experiment Perilous follows the attempts of psychiatrist Dr.

Huntington Bailey to unravel the truth behind the rich and mysterious Bederaux family. Bailey meets ageing spinster Cissie Bederaux on a train to New York, where she tells Bailey about her brother Nick and his beautiful wife Allida. Cissie dies in mysterious circumstances, and Bailey's sculptor friend Clag introduces the doctor to Nick and Allida, who are his artistic patrons. Although Nick continually alludes to the precarious state of his wife's mental health, Bailey suspects that it is Nick himself who is unstable and secretly tormenting Allida. Bailey reads Cissie's diaries, which tell him of Nick's troubled childhood, his transformation of Allida from a country girl to the society debutante who he then married, and hint that he may have murdered one of Allida's suitors in a fit of jealousy. Nick realizes that Bailey and Allida have fallen in love and plots to kill them via an elaborate plot that Bailey is able to foil with some quick-witted psychoanalysis. Nick is killed in an explosion that destroys the Bederaux mansion, leaving Bailey, Allida, and her son Alex to live happily ever after in the countryside.

The complexity of Experiment Perilous's plot is mirrored in its narrative structure, which relies heavily upon flashback sequences and moments of subjective sound to explain the connections between various aspects of the story. Despite its location within the 
investigatively focused gaslight cycle, the film sidelines Allida's role in uncovering the truth about Nick until well into the narrative. Instead, the detective work falls primarily to Dr. Bailey, although he is (posthumously) assisted here by Cissie-whose observations and recording of family history become key elements of Bailey's evidence against Nick. Bailey's mutually dependent roles as doctor and detective ensure his centrality to the criminal and romantic elements of the film, and the film's structure further emphasizes his subjectivity and narrative control: all of its flashbacks and reminiscences (even those relating to Cissie's childhood) are filtered through his eyes and ears. The doctor-detective is here the source of the narrative itself, as well as one of its key protagonists.

Bailey's narrative dominance is immediately made clear in the film's opening scene, where his voiceover introduces Cissie:

Bailey: I remember clearly everything that happened that night, for that was when it started innocently enough on an East-bound train. It was in the early spring of 1903 to be exact, and the train was plowing through a heavy storm. I had been napping, and I awoke to find a woman watching me, smiling, a bird-like sort of little woman. But behind that smile I thought I could see something of terror in her eyes. She was badly frightened by the storm and she asked me if she could sit by me - she said it would make her feel safer. I reassured her to the best of my ability and wondered vaguely if she were mentally ill. I found out later that she was nothing of the sort. But now she seemed to read my thoughts...

During this opening voiceover, the noise of the train remains audible but other diegetic sound, including Cissie's dialogue, is absent. As Bailey's voiceover fades out and the sound design becomes more conventional, his conversation becomes audible: 
Cissie: Why, you're a doctor aren't you?

Bailey: How did you know?

Cissie: Oh, I know a lot about doctors, there's something alike about them all. The fat ones, the thin ones, the homely ones, and [here she indicates Bailey] the good-looking ones. It's as if they were looking at something beneath the flesh, something that does not change.

This scene establishes two important and interrelated features that help to create and reinforce Bailey's narrative agency: his profession as doctor (and the access that this gives him to both the physical and mental state of his "patients"), and his control over the film's soundtrack (which is heavily reliant on his medicalized authority). Bailey effectively speaks for Cissie in the first half of this sequence: in addition to the whole sequence (and the film itself) being positioned as a flashback narrative, his subjective remembrance of dialogue replaces its actual presence. This narration heavily influences our initial response to Cissie, who, we are told, is a nervous, jittery, "bird-like little woman." Bailey's initial assumption that Cissie is mentally ill because she looks frightened is given credence (despite his immediate retraction) by Cissie's own familiarity with the doctor's ability to "see beneath the flesh," which again ties physical appearance and response to emotional and mental wellbeing. Bailey is immediately cast in the role of rescuer and protector; not only because of his own account of the reassurance he offers to Cissie, but also through her evident appreciation for the expert, perceptive gaze and reassuring "bedside manner" of the medical professional. This is presented as the reason for Cissie's instant trust of Bailey, and motivates her stories about Nick and Allida upon which the gaslighting plot itself hinges.

From the opening scene of Experiment Perilous, Bailey's medical knowledge is key in giving him the access and authority upon which the detective-figure most commonly depends: he is able to transcend usual class barriers and gain access to the Bederaux mansion, 
and other characters trust him and will accept his questions as resulting from professional, rather than personal interest (although this is a boundary that becomes increasingly fluid as the narrative progresses). Medical discourse is the film's key positioning device, and intersects with gendered identity in a relatively traditional manner. It shores up the healthily intellectualized masculinity of the doctor-Bailey takes every possible opportunity to demonstrate his diagnostic skills — and highlights the nervous nature of Cissie and Allida as female "patients" over whom Bailey wields a calming influence. Medical discourse also reveals Nick's insanity, portraying him as overly bookish and hysterical. Although Nick initially appears to be well read about psychology and psychiatry, his misleading and malicious diagnoses of the stage-managed symptoms of Allida are dismissed by Bailey as out of date "hocus-pocus": his genuine vision reveals that it is Nick himself who displays the feminizing hallmarks of mental fragility.

As the opening train scene with Cissie demonstrates, Bailey's medical authority is tied up with his control of the soundtrack, which functions not only as a device to communicate elements of mood, tone, and characterization, but also as a means of reinforcing the doctor's control over the text as a whole. The majority of the soundtrack can be theoretically positioned as subjective because of its presence within the Bailey-generated world of the flashback ("I remember clearly everything that happened that night..."), ${ }^{30}$ and the film's nondiegetic orchestral score engages with and reflects Bailey's love for Allida, his memories of Cissie, and his fear of discovery by Nick. In addition to Bailey's "ownership" of the majority of the film's nondiegetic cues, the connections between sound, music, and the doctor's experience are made obvious through the use of voiceover and frequent "moments of memory." These sequences show Bailey pausing to remember lines of dialogue or snippets of music that are significant in his understanding of the Bederaux mystery, allowing us to

\footnotetext{
${ }^{30}$ Only the credits sequences and final epilogue sit outside this flashback.
} 
eavesdrop on his thought processes and reinforcing the doctor's dominance as author-narrator even when the use of voiceover itself is absent. Like the use of medical discourse, they intellectualize Bailey's responses to characters and to the "case" so far, presenting detection as a largely interior, solitary activity — a puzzle to be solved, rather than physically wrestled with (although Bailey also demonstrates elements of a more traditionally forceful masculinity in his final showdown with Nick). The doctor-detective offers an investigative approach that combines the gentrified sleuthing methods of the "golden age" crime writers of the 1920s and 30s with the emphasis on psychology more commonly associated with the rough-and-tumble detectives of film noir and the hard-boiled school. ${ }^{31}$ The construction of Bailey's masculinity therefore demonstrates not only the ways in which his personal and professional identities are used to draw together the romantic and criminal elements of the plot, but also the ways in which these identities can be considered representative of the female gothic's evocation of a genteel-but-creepy atmosphere (here heightened given the period setting that identifies Experiment Perilous as a gaslight narrative) and its simultaneous engagement with the Freudian themes and interiority more commonly associated with 1940s crime cinema.

Bailey's moments of memory most commonly feature him recalling the words of Cissie, whose (suspected) murder forms an important part of his initial motivation to meet Nick and Allida. Cissie's characterization is in some ways less straightforward than that of the other protagonists; as the opening train conversation demonstrates, she is at once jittery, frail, perceptive, and engaging, and although she is a key figure in the successful resolution of both the romance and criminal plots, the majority of her role is played out after she is dead. This dual presentation of Cissie is facilitated by the control Bailey wields over the narrative, and is aurally symbolized not just in his ability to replay her dialogue at will (as he does with

\footnotetext{
${ }^{31}$ Stephen Knight, Crime Fiction, 1800-2000: Detection, Death, Diversity (Basingstoke: Palgrave Macmillan, 2004).
} 
various other characters), but also in the recurring use of a musical motif associated specifically with his experience of her. This is introduced as diegetic piano music at the party where Bailey hears about Cissie's death (Example 1). Its somber, sequential movement and descending bass line give it a feeling of sadness and gravity that provides a noticeable contrast to the lighter, flashier music played at the party up until this point. ${ }^{32}$ As this music plays, we see Bailey absorbing the fact that Cissie has died whilst Clag's new sculpture, "Woman," watches over him (Figure 1) — a visual representation of the catalytic role Cissie will play in Bailey's investigation.

\section{<Fig. 1 and Ex. 1 together around here>}

The idea of Cissie's investigative legacy is played out musically, in the reuse of the "Cissie" material to provide orchestral background scoring as Bailey recalls her previous dialogue, and is also present in the plot device of her diaries, which the doctor uses to glean important information about Nick's troubled past. Both of these strategies also point to the ways in which Cissie's posthumous narrative agency is further contained within the textual framing device of Bailey's stressed subjectivity. The "Cissie" material acts primarily as a marker of Bailey's reaction to her death, rather than indicating any particular characteristics or experience of Cissie herself — an association underlined by its subsequent reuse at moments significant to Bailey's active investigation of the Bederaux family (an investigation

\footnotetext{
${ }^{32}$ The previous party cue is taken from Chopin's Waltz no. 7 in C-sharp minor. This original presentation of the "Cissie" material also recalls Chopin (particularly the Prelude Op. 28, No. 4 in E minor) and is relatively typical of the overall styling of the film's diegetic music, which tends to utilize a Viennese art music idiom (drawn both from preexisting concert music and cues written to pastiche this style). The European styling of these pieces is evocative of the privileged Viennese ancestry of the Bederaux family, and highlights the film's period setting and Nick's role as an artistic patron.
} 
that Cissie could not bring herself to start, despite her tacit suspicions of Nick). The narrative's central diary sequences, where Bailey reads Cissie's personal papers to gain valuable insight into Nick's childhood and his relationships with both the Bederaux women, are framed by shots of Bailey's examination of Cissie's handwriting and his auditory recollection of the "Cissie" material. In a move that inverts the relationship between present body and absent speech of the opening sequence, Cissie's voice narrates the extracts from her diary to introduce sections of narrative based on these events. However, the usual authority of the author-narrator is tempered by Bailey's presence: this whole sequence functions as a second-level flashback within a flashback: what we see and hear is positioned as Bailey's reconstruction of Cissie's story, and this is further mediated by the scene's position within the Bailey-generated world of the diegesis itself. The orchestral version of the "Cissie" material is heard for the last time when Bailey meets Allida in a restaurant after finally realizing the true meaning of the clues provided by Cissie's dialogue and her diary. This sequence acts as a coda to Cissie's narrative and musical presence; it reiterates her significance within the plot's development, but also marks the point at which her role as catalyst is effectively complete. This leaves Bailey and Allida's romance, and its music, to take center stage.

This romance music provides Experiment Perilous with its primary musical signature, "Allida," a dominant and recurring leitmotif that is first heard in the expansive and romantic opening credits and then goes on to dominate scenes associated with or featuring Allida herself (Example 2). A conventional reading of the score might label this motif as "Allida's theme" or perhaps the "love theme," and its placement within the narrative (and the stylistic approaches taken to it) could certainly be used to support this interpretation. However, this reading overlooks the connections between the soundtrack and the stressed subjectivity of Dr. Bailey, as well as the problematic positioning of Allida herself within the narrative. This musical material symbolizes Allida, but it is not her theme: it is part of the film's (and 
specifically Bailey's) discourse about her, rather than by her, and can be considered as one of the many devices present that are used to position Allida and contain her agency.

\section{$<$ Ex. 2 around here $>$}

Even before Nick's gaslighting plot has come to prominence, Allida's position as a victim has been firmly established: her physical appearance withheld until relatively late into the narrative, she is continually marginalized, presented as a beautiful but ultimately helpless and fragile woman in need of (Bailey's) rescue. Allida's beauty is thematized throughout Experiment Perilous. At first, this seems to function primarily to heighten expectation and to reinforce actress Hedy Lamarr's star image as a major Hollywood beauty, but as the narrative develops Allida's appearance becomes an increasingly potent signifier of the way in which she is misunderstood by society and repressed by Nick. In its intersection with the film's medical discourse, it also draws direct comparison between the heroic masculinity of Bailey and Nick's flawed effeminacy, whilst ensuring that female characters remain contained and objectified.

The idea of Allida as repressed and trapped is potently symbolized by her portrait, commissioned by Nick and on public display in the Bederaux wing of the museum, where Bailey gets his first glimpse of his future wife. The presence of portraiture in film (a notunusual feature of female gothic films and film noir) can invoke a range of signifiers, but the painting is here used primarily to highlight themes of Nick's material wealth and Allida's own beautiful perfection. ${ }^{33}$ Allida is portrayed as a distant but desirable object, framed for

\footnotetext{
${ }^{33}$ Mary Ann Doane, The Desire to Desire, 142-43; Thomas Elsaesser, "Mirror, Muse, Medusa: Experiment Perilous," Senses of Cinema 18 (2002), http://sensesofcinema.com/2001/18/perilous/; Helen Hanson, Hollywood Heroines, 77-96.
} 
public consumption as a kind of trophy: in viewing the portrait, Bailey is therefore drawn into the first of an uncomfortable series of comparisons with Nick. The musical construction of this scene is important in (partially) protecting Bailey from these comparisons with the film's villain, and care is also taken to preface this sequence with demonstrations that Bailey's "vision" is not like that of other men:

Elaine: I think Allida's the most beautiful woman I've ever seen.

Clag: She's a work of art.

Bailey: I don't like beautiful women. It makes them nervous. As well as highlighting the doctor's tendency to collapse physical and mental attributes together, the difference of opinion, or value, implied in this statement is crucial in ensuring Bailey's positive presentation and continuing authority within the narrative. Bailey is portrayed throughout Experiment Perilous as valuing a beauty that goes beyond surface appearance to encompass issues of character, taste, and morality. With his privileged position as physician, Bailey has access to these elements as well as the surface-level beauty that the artist community and Nick are concerned with. Bailey's scientific vision sees through the potential artifice and disguise of surface attractiveness, to offer the most complete and "accurate" vision of (feminine) beauty. ${ }^{34}$

As well as the (often-subtle) uses of the "Allida" motif when either Bailey or someone he is talking to mentions Allida, this positioning is most obviously highlighted in the presentation of the "Allida" material as Bailey views her portrait in the museum. This short but significant sequence segues musically out of the previous cue, which uses the "Cissie" material to underscore one of Bailey's subjective voice-memory moments (here recalling

\footnotetext{
${ }^{34}$ A point reinforced by the film's (somewhat-contrived) ending: Bailey wins Allida's hand in marriage after Nick is killed by a falling statue of his "favorite goddess," explicitly punishing him for his attempts to capture and objectify femininity.
} 
some of Cissie's words to him on the train, and Clag's attempts to pique his interest in Allida's portrait). After a brief establishing shot of the museum exterior, we see an overhead shot of Bailey approaching the portrait as the camera gradually closes in on his face. He looks intensely at what is revealed to be the portrait. The camera returns to Bailey and then again to the portrait, this time in a close-up of Allida's face (Figure 2). This camerawork replicates a conventional shot-reverse-shot setup, forging a connection between Bailey and Allida but with the crucial difference that only Bailey is an active participant in this exchange of glances-Allida is present only in her portrait. As this camerawork unfolds, we hear a prominent presentation of the "Allida" motif on solo violin, supported by the rest of the orchestra (Example 3). Expressive use of rubato and portamento intensify its signification of emotion, and chromatic manipulation of the original "Allida" material is combined with descending harmonic movement to produce a melancholic affect that imbues the scene with wistfulness.

\section{< Fig. 2 and Ex. 3 together around here>}

Allida's painted expression and Bailey's face are similarly inscrutable, leaving the score to articulate both his emotional response and the idea that Allida is a tragic heroine, rather than the merely "fateful" beauty we have heard so much about. This musical accompaniment is therefore significant in redeeming some of the problematic connotations of Bailey's gaze upon the portrait: by emphasizing the emotional impact of the painting as a representation of a victimized Allida, the cue prevents the positioning of Bailey as merely another celebrant of her objectified beauty. However, the clear connection this cue has with Bailey's subjective response to the painting also establishes a problematically hierarchical relationship between Allida as trapped victim and Bailey as heroic, perceptive rescuer and 
"owner" of the musical material that represents her: a gendered hierarchy of control that is perhaps not so very different from the desire to commodify and contain her beauty that motivated Nick's commissioning of the portrait in the first place.

Despite these problems, the importance of these preemptive strategies in the film's intended valorization of Bailey's “vision" becomes particularly clear when we finally meet Allida in the flesh: in a striking repetition of the static image of the portrait, a tight close-up congruent with Bailey's perspective shows Allida dressed in an identically ornate and constricting high-necked black gown, pouring tea with a fixed and distant expression on her face. The claustrophobic and controlling atmosphere of the Bederaux marriage is immediately clear to Bailey when Allida tells him that Nick designed her gown and that it "pleases him" for her to wear it. Nick's attempts to obscure the real Allida behind a controlling mask of high society grooming are contrasted with Bailey's immediate understanding of the genuine beauty present in her natural "country" looks. Bailey describes Allida's portrait as "disturbing," and his own account of how he would paint her underlines the accuracy of his response, emphasizing a rural setting and moving away from the objectification of her face:

Bailey: If I were painting her I'd do her quite differently. It wouldn't be a solemn face, or a woman dressed up behind a tea tray. I'd paint her full length for one thing — in a country field with the sky beyond. Long grasses to her knees and the wind blowing across the field. ${ }^{35}$

Nick's control of Allida, which culminates in the film's gaslighting plot, is reinforced in a montage that summarizes their courtship using the information contained in Cissie's

\footnotetext{
${ }^{35}$ Cissie is the only other character to have any understanding of the real Allida, although her vision is also unreliable: she not only emphasizes Allida's "dear" and "sweet" character, but also emphasizes her beauty on the train with Bailey and later describes her as a "child," infantilizing her in a similar way to Nick.
} 
diaries. We see Nick's Parisian regime of training for the young Allida, where she takes language, ballet, and singing classes ready for her entrance into French society. After her marriage to Nick, this sequence culminates in Allida's self-accompanied performance of a French song at her birthday party, where the idea of artistry and beauty as commodities for exhibition rather than emotional communication is made abundantly clear. ${ }^{36}$ Nick is exhibiting his wife's "talents" to a sycophantic audience of the artists reliant on his patronage. When Clag offers Allida his congratulations on her performance his words expressly recall the objectification she faces in her portrait, and make clear the real reasons behind her position as Nick’s "prize":

Clag: It isn't your voice my dear. When you sing we can stare at you without embarrassment.

Despite the care taken to distinguish between the flawed vision of Nick and the heroic viewpoint of Dr. Bailey, this section of the diary flashback makes clear the extent to which Bailey's control of the soundtrack functions to objectify Allida and limit her agency. Nick's control of Allida's diegetic musical characterization and performance mirrors the way in which Bailey's ownership of the "Allida" motif reinforces the problematically hierarchical medical discourse upon which their doctor-patient relationship is founded (which in turn recalls Bailey's effacement of Cissie's vocal presence and control of the "Cissie" material). Whilst the unmasking of Nick's insanity ensures that his treatment of both Allida and Cissie appears abhorrent, Bailey's engagement with these women takes place in the guise of the valiant doctor-detective who collapses the registers of the personal and professional together in his ability to see (and hear) "beneath the flesh" to identify and fulfill their needs. Bailey’s musical and medical control therefore intersect in a mutually beneficial and circular

\footnotetext{
${ }^{36}$ Although by no means an unusual practice in the studio era, the obvious use of dubbing to provide Allida's singing voice in this sequence further highlights the staged, artificial nature of her performance.
} 
relationship designed to uphold the intellectualized, authoritative masculinity of the physician while perpetuating cultural links between femininity, frailty, and the pathological that ensure the silencing of Cissie and Allida. ${ }^{37}$

\section{"The Weak And Imperfect Of The World"-The Female Mute As Victim In The Spiral}

\section{Staircase}

The Spiral Staircase uses the period mansion setting of the gaslight film as a basis for a more straightforward serial killer narrative. Set in New England around the turn of the century, the film focuses upon the search for a murderer who targets women with "afflictions," beginning with a scene where we witness the murder of a young woman who walks with a limp. After examining the body, Dr. Parry offers a lift home to Helen, a servant at the Warren house. Helen flirts shyly with Parry and is revealed to have been mute since witnessing the death of her parents in a fire. Parry is called away to a patient, leaving Helen to walk through the woods alone. A storm starts, and we see the shadow of the killer watching her as she enters the house.

Inside, we meet the formidable but bedridden Mrs. Warren, her son Steven and his stepbrother Albert (an academic Professor whose live-in secretary, Blanche, is romancing

\footnotetext{
${ }^{37}$ Allida's relative lack of agency throughout the majority of Experiment Perilous is highlighted by the film's epilogue, where a District Attorney arrives at Bailey and Allida's country home to question her about Nick's death. Allida's retaliatory arguments display a spirit and confidence previously seen only in flashbacks to her country upbringing, and the D.A. leaves full of "admiration" for her. As Allida runs towards Bailey and Alex, a full orchestral presentation of "Allida" accompanies her, and can be read, this time, as representing the subjectivities of both Bailey and Allida, who are now portrayed as much more equal partners. In part this is because of the absence of Nick's controlling influence, but it is also because the medical discourse/gaslighting plot surrounding Allida's mental health has now been played out, and Bailey has moved from the position of doctor-detective to a more conventional and straightforward rendering of the romantic lead-as symbolized in the shift from "his" flashback to the present.
} 
Steven). Helen is warned to be careful, as her muteness makes her a target for the killer. Suspense builds as we realize that all the men in the house, as well as Dr. Parry (who makes frequent visits to Mrs. Warren's sickbed), are potential suspects. Parry urges Helen to seek treatment for her muteness and offers to take her to see a specialist, and Mrs. Warren also insists that Helen leave the house before she is killed. Helen agrees to leave that night. Blanche also decides to leave but is strangled by the killer, leaving Helen to find her body in the basement. Helen suspects Steven of the killing and manages to lock him in the wine cellar, but then realizes that she has captured the wrong man and left herself alone with the real murderer, Albert. Albert's pursuit of Helen is cut short when Mrs. Warren rises from her sickbed to shoot him, before collapsing herself. A traumatized Helen regains her voice, screams, and staggers to the telephone to call Dr. Parry.

As in Experiment Perilous, the medical discourse of The Spiral Staircase collapses the realms of the physical and mental together: Helen is mute because of psychological trauma, and the "afflicted women" that have fallen prey to the serial killer include both those with physical disability and a "poor, simple-minded creature." The soundtrack is again an important factor in the construction and (often simultaneous) containment of agency for various characters, including Helen as victim, Albert as killer, and Dr. Parry as the film's authoritative male. However, these gendered roles and identities are not always as clear cut as those in Experiment Perilous. This is partially due to the more conventional narrative structure of The Spiral Staircase, which eschews voiceover and flashbacks in favor of an accelerated timeframe that situates its events over the course of one afternoon and evening. As well as giving an air of immediacy that heightens tension, this removes the controlling presence of an author-narrator figure and allows the film to stress the experience and 
reactions of various characters at different points in the story. ${ }^{38}$

As the film's most commonly present character and its central victim, Helen's subjectivity is regularly highlighted: The Spiral Staircase is essentially a gothic-horrorwhodunnit take on the female gothic narrative, and audience identification with the victim is therefore an important element in the creation of suspense and delivery of shocks. More unusually, the film also makes frequent use of the (anonymized) murderer's point of view, which is strikingly emphasized in several sequences that use a shot-reverse-shot setup to show the killer's eye followed by a distorted point of view image of his victim. These pointof-view shots appear to be formed by combining static photography of the eye with a superimposed moving image of the victim, giving the composite image a curved frame that highlights their provenance as point of view and suggests that the killer's insanity has (literally) warped his vision. These shots occur during the opening murder sequence (see frames 3 and 4 of Figure 3), when Blanche is killed, and during a sequence where Helen examines herself in a mirror-where the killer's obsession with Helen's "affliction" is visually rendered by the replacement of her mouth with a blurry, amorphous blot.

This striking nature of this camerawork is matched in the soundtrack by the prominent use of the Theremin as a musical signifier of the killer's presence. Although not a common instrument in film or television scores, the synthetic timbre, forced glissandi, and wide

\footnotetext{
${ }^{38}$ Another important point of similarity and departure between the two films is their casting of George Brent as the male lead: Brent plays Dr. Bailey in Experiment Perilous and Professor Warren (Albert) in The Spiral Staircase - casting perhaps designed to capitalize on his portrayal of Dr. Frederick Steele in the celebrated 1939 Bette Davis vehicle Dark Victory. Although quite clearly very different characters (Bailey is the heroic rescuer, and Albert the effeminized, psychotic killer), this casting choice emphasizes the strong overlaps between these bookish, academic leading men, and their difference from the more usual gamut of Hollywood masculinitiesas well as the role of the soundtrack in ensuring we are steered towards a "correct" understanding of their contrasting moral and manly qualities.
} 
vibrato that characterize the sound of the Theremin developed a particular association with science fiction. ${ }^{39}$ It also features occasionally in films depicting madness or mental illness, where its oscillating pitch and difficulty in combining smoothly with the orchestral texture make it an ideal tool in the illustration of instability, otherness, or loss of control. ${ }^{40}$ The Spiral Staircase combines the use of the Theremin as a kind of "leitinstrument" for the killer with a three-note motif used to signify the murderer's presence (Example 4). The opening perfect fifth of this motif acts as a kind of passing note, emphasizing the tritone between $\mathrm{F}$ and $\mathrm{B}$, with its connotations of ambiguity, deviance, and evil. Working alongside the point of view camerawork in these sequences, the Theremin motif can be understood as indicating the killer's subjectivity as well as his presence. It replaces breathing, heartbeats, or other physically produced subjective sound (used in many similar horror film sequences) with a musical representation of his response to unfolding events, and one that renders his difference and instability in sonic form. The Theremin motif therefore serves a dual purpose: it functions as a conventional (nondiegetic) leitmotif by appearing whenever the killer is onscreen or about to strike, and also plays an important part in his feminization through its sonic connotations of hysteria and madness - a relationship that suggests it functions at a subjective

\footnotetext{
${ }^{39}$ James Wierzbicki, "Weird Vibrations: How the Theremin Gave Musical Voice to Hollywood's Extraterrestrial ‘Others,”’ Journal of Popular Film and Television 30/3 (2002): 125-35.

${ }^{40}$ Most famously including Miklós Rózsa's use of the Theremin to represent mental distress caused by alcoholism in The Lost Weekend (1945), and the effects of amnesia and a "guilt complex" in Spellbound (1945). Spellbound, in particular, contains some striking parallels with the way in which the score for The Spiral Staircase draws connections between musical depictions of "love" and "madness" or threat, and it seems likely that Rózsa's score for Hitchcock's recently released thriller (and the themes and tenor of Spellbound more broadly) influenced the production of Staircase. Peter Franklin, Seeing Through Music, 139-46; Albert Glinsky, Theremin: Ether Music and Espionage (Urbana: University of Illinois Press, 2000), 253-55.
} 
level of the soundtrack as well. ${ }^{41}$

\section{$<$ Ex. 4 around here $>$}

The film's discourse about the nature of "true" masculine becomes particularly obvious in relation to the Warren brothers. Albert is portrayed as a finicky, pedantic academic, especially when compared with his stepbrother, the easy-going, boyishly handsome, and romantically successful Steven. However, neither of the Warren brothers is portrayed as a "real" man, and are positioned as falling short of their late father's idea of masculinity, as Steven highlights:

Steven: Let's stop sparring. You're angry because I took Blanche out.

You're angry because since I've been home Blanche and I have gotten to know each other pretty well.

Albert: You know Steven, you always did smirk. Even when you were a child. It's one of the things my father didn't like about you.

Steven: He was my father too. You know, I'm inclined to think that father was disappointed in both of us. Neither of us fit his idea of what a real man should be: a gun-totin', hard-drinking, tough-living, god-fearing citizen.

Mrs. Warren also refers to her late husband's disappointment with his "weakling” sons, as well as to her own masculine prowess: she describes herself as being "as good as any man," and saves Helen's life when she shoots Albert at the film's climax. Even before his unmasking as the murderer, Albert is portrayed as fragile, bookish, and unable to stand up to

\footnotetext{
${ }^{41}$ Although this feminization also occurs in Nick's presentation in Experiment Perilous it is much less obvious; partly because the gaslighting plot requires that he stays credibly "sane" until relatively late in the narrative, but also because Bailey's dominating presence provides a constant reminder of Nick's failure to measure up to the masculine ideal that he provides.
} 
his stepmother: Mrs. Warren is a powerful and overbearing figure, despite her age and ill health, and Albert tells Steven that caring for her has made him "tired and strained." The film suggests that Albert has buckled under the weight of his father's (and stepmother's) expectations, as well as the way he compares himself unfavorably with Steven (Mrs. Warren notes that there is "always trouble" when Steven comes back from his European trips). Albert compensates for his lack of rough-and-tumble manliness with academic overachievement and the eventual use of murder as a means of gaining control over women who are "afflicted," or who reject him. ${ }^{42}$ He explains his actions as he prepares to kill Helen:

Albert: Blanche, whom I loved, didn't love me. So she had to die. She's dead, and at peace. And Steven, you took care of him for me. Steven is weak, as I once was. What a pity my father didn't live to see me become strong. To see me dispose of the weak and imperfect of the world whom he detested. He would have admired me for what I'm going to do...

Our enforced identification with the killer, his madness, and the feminization of his condition are all introduced in the opening scenes of The Spiral Staircase, which also mark the start of our identification with Helen as heroine and victim. After a brief series of establishing shots of a hotel exterior and lobby, we are shown a silent film screening with live piano accompaniment taking place inside, a sequence summarized in Figure 3. Although the silent film is identified as The Kiss, the footage actually shown in The Spiral Staircase is from The Sands of Dee (1912), a short film based on a Charles Kingsley poem describing the

\footnotetext{
${ }^{42}$ Steven's European trips, on the other hand, mean that he has been able to leave the claustrophobic, domestic, and feminizing atmosphere of the Warren mansion, and his mother and stepbrother, behind. His cultured cosmopolitanism, especially when compared with Albert's stiff pedantry, is reflected in his more casual dress, his confident and graceful social interactions, and his musicianship: Steven's lighthearted, improvisatory piano playing and singing is used to tempt Blanche away from her secretarial work, much to Albert's displeasure.
} 
suicide of a girl who is jilted by her lover. We see shots of the film, the accompanist, and the audience, focusing in particular upon one young woman (Helen), who is perhaps less expensively dressed than many of the other women present and seems engrossed in the events unfolding on screen. The camera lingers on Helen's face before gradually angling upwards, and the scene dissolves to that of one of the hotel's upstairs bedrooms. Here, we see a woman who limps heavily as she shuts the open window and moves towards her closet to find something to wear. As she takes out a gown and moves away, the camera remains focused upon the closet, zooming in to reveal a watching eye and setting up the killer's point of view shot. The camera cuts to show a close-up of the woman's hands above her head, frozen in the act of putting on her dress by the lunge of the killer. Her hands claw fruitlessly at the air as she chokes and then goes limp. The camera cuts back to the hotel theater, where the silent film shows the suicide victim's body being carried back home. As The Sands of Dee concludes with an intertitle reading "THE END" and the piano player reaches the final cadences of the accompaniment, we hear the crash of the real-life victim's body hitting the floor above.

\section{$<$ Fig. 3 around here, with all stills on the same page $>$}

This sequence introduces the female victim as one of the primary themes of The Spiral Staircase, and demonstrates the way in which the film continually forces us to identify with both victim and killer. Helen, silently watching the distressing events of The Sands of Dee, occupies a position analogous to that of the cinema spectator, and we are explicitly encouraged to identify with the murderer's anticipation of his kill through the use of point of view camerawork. The killer (another voyeur) is literally closeted amongst the feminine clothing in the wardrobe, and the prominent sound of the Theremin ties his distorted vision and murderous violence clearly to ideas of madness and instability. Although we do not yet know who Helen is, the repeated focus on her face as she dabs away tears of empathy, 
intercut with shots of the female victims of the silent film and the murder upstairs, connects her with themes of persecution and victimization. It also draws parallels between her yet-tobe-revealed muteness and the enforced silence of these other victims, who are voiceless because of technology (the silent film), or violence (strangulation that removes the victim's chance to scream).

The scene also draws attention to the communicative properties of the soundtrack as part of the cinematic experience, highlighted by the diegetic presence of the piano player and the interplay of this music (the opening movement of Beethoven's Piano Sonata No. 8 in C minor, Op. 13) with the various elements of the orchestral score. The orchestra enters as the camera zooms in towards the closet, with tremolo strings and increasing chromaticism building tension before the Theremin enters with the killer's motif as we cut to the close shot of his eye. All three elements of the music continue and crescendo during the murder, before the "nondiegetic" parts drop out as we return to the auditorium, leaving the pianist to finish the sequence alone. Example 5 shows a section of this complex musical texture, which can theoretically be understood as exploiting diegetic, nondiegetic, and subjective levels simultaneously; the piano and the orchestral parts are taken from the conductor's score, with the Theremin part added manually.

\section{$<$ Ex. 5 around here $>$}

Although the Theremin itself is reserved for those scenes featuring the anonymous murderer, much of the musical material used in the film's score is connected to the three-note killer's motif. This generates tension by carrying its musical characteristics through to less obviously "threatening" cues, reinforcing the classic whodunit structure of the narrative where all the men remain plausible suspects for as long as possible. The score's other major recurring motif has strong similarities to the killer's motif, despite its general use as a love theme associated with the relationship between Helen and Dr. Parry. Although this second 
theme appears in several sequences that feature Helen alone, its first appearance within the narrative establishes it as a marker of Helen and Parry's romance, rather than Helen as an individual.

The shared ownership of this theme is reinforced by Parry's diegetic whistling of the tune to Helen, as shown in Example 6. This whistling occurs as Parry gives Helen a lift part of the way home after the first murder has taken place. Nondiegetic scoring features in most of the sequence, establishing a peaceful and pastoral mood appropriate for the romance that is obviously simmering between the two characters. Parry whistles the first four notes of the theme underneath high, sustained strings (highlighting the transition between the second and third notes with a shift in harmony), and then asks Helen if she knows the words to "that tune." Helen smiles and looks coy, and Parry proceeds to whistle the next four notes as the nondiegetic score continues to accompany him. ${ }^{43}$ His whistling gives Parry primary control of the theme at this point, as Helen's muteness excludes her from any active or audible participation in his recitation. The whistling functions in subsequent scenes to evoke Parry's presence as Helen's suitor, even when he is physically absent. In addition to its potential to symbolize her romantic desires, the love theme can also be used to diminish Helen's agency by reinforcing the idea of her vocal "lack" - an attitude that, as will become clear, is articulated primarily through the medical discourse of Dr. Parry himself. The love theme's structural connections with the killer's motif (outlined in Example 7) also reinforce Helen's victimization through their articulation of the overlap between the warped vision of the killer and Parry's medicalized misogyny. They generate suspense about the doctor's true motivations (he is a plausible suspect until well into the film), and highlight the similarities

\footnotetext{
${ }^{43}$ What "that tune" might be is unclear, but it seems likely that Parry's remark refers to a real or imaginary popular song with a romantic theme.
} 
between Parry and the killer's view of Helen's muteness as an "affliction" in need of cure. ${ }^{44}$

\section{$<$ Ex. 6 and Ex. 7 around here $>$}

Helen's muteness is the primary focus of medical discourse in The Spiral Staircase, and has significant implications for her presentation and engagement with other characters (and the cinema audience). In Ethel Lina White's Some Must Watch, the source novel for the film's screenplay, Helen is not mute; instead the killer's murderous obsession with her stems from a misogynist desire to rid the world of "superfluous women." 45 Here, Helen's crime is to be merely ordinary, but the film adaptation rejects this as a convincing motivation for murder and instead chooses to focus on the idea of "afflicted" women. This adds a second layer of victimization to the portrayal of the killer's targets that is reinforced by the pitying phrases used to describe the various physical and mental disabilities that ail them.

In her work on female vocality in classical Hollywood, Amy Lawrence argues that the treatment of Helen can be considered emblematic of the way in which these films deal with the problem of the speaking woman: although Helen's muteness can be read as a signal of willful rebellion, it also allows Parry to "position her in ways which appeal to him," and her final speech is only permitted once the narrative has ensured her submission to the patriarchal order. ${ }^{46}$ Helen's presentation shifts throughout the film as the controlling influences of Dr.

\footnotetext{
${ }^{44}$ The close relationship between the killer's motif and the love theme is established in The Spiral Staircase's brief opening titles, which superimpose the credits over an aerial shot of Helen slowly descending the spiral staircase to the Warren basement, as a storm rages outside. After an opening fanfare that accompanies the RKO radio mast emblem, the Theremin introduces the killer's motif over the sound of the storm (establishing the almost-constant sound of the wind, rain, and thunder that characterizes much of the film's tense and effective sound design), which segues into a minor-key version of the love theme.

${ }^{45}$ Ethel Lina White, Some Must Watch (London: Ward, Lock, \& Co., 1933).

${ }^{46}$ Amy Lawrence, Echo and Narcissus: Women's Voices in Classical Hollywood Cinema (Berkeley: University of California Press, 1991), 115. Silverman's discussion of the ways in which classical film contains female
} 
Parry and Albert become increasingly apparent. Her early interaction with other characters presents her as a popular, engaging, and contented woman, who is not cowed by the grim warnings she receives about the killer. Instead, Helen is resourceful and practical: when startled by a noise as she walks home through the isolated woods, she immediately arms herself with a broken branch, clattering it along iron railings to dispel her fears, announce her presence, and defend herself if necessary. Helen's agency therefore comes from seemingly contradictory sources: her explicit positioning as both potential victim (of the killer) and actual victim (of her muteness) cements her position as the narrative's central heroine figure, and her simultaneous refusal to conform to this positioning or accept her muteness as either disability or lack celebrates her independence and feisty disposition.

However, Helen's acceptance of her muteness changes through the course of the film, and she eventually comes to occupy a position in relation to her voice in line with that of the medical discourse introduced by Dr. Parry. The doctor diagnoses Helen's muteness as a physical manifestation of mental trauma - the shock and guilt she felt at the death of her parents - and views it as a problem she must overcome to progress in any way. Parry talks dismissively about the work that Helen does at the Warren house, and his insistence upon her cure implies that her disability may also prove to be a barrier to their romance. ${ }^{47}$ Although Parry's medical training and connections can provide his patient with a means of treatment, he clearly views Helen herself as the root cause of her muteness: she is simply not trying hard enough to speak. Two sections of Parry's dialogue demonstrate these ideas particularly clearly. During the carriage ride Parry precedes his whistling of the love theme with remarks voices within clearly defined "textual spaces" is also pertinent here. Kaja Silverman, The Acoustic Mirror, 5661.

\footnotetext{
${ }^{47}$ This is typical of the cinematic depiction of the female mute, who may be desirable but is rarely part of a couple unless she can be induced to speak. Michel Chion, The Voice in Cinema, trans. Claudia Gorbman (New York: Columbia University Press, 1999), 99; Heather Laing, The Gendered Score, 27-28.
} 
about Helen's lack of effort in seeking a cure:

Parry: I got to wondering how long you're going to go on like this. I mean doing the work you're doing at the Warrens'. You used to want to be a nurse or a teacher. You mean you're going to give up that, without making an effort to get your voice back again? Yes, I know Helen, you did see a doctor once, but that was a long time ago - they might have discovered a lot since then. There are specialists in Boston now. I don't want to build your hopes up Helen, but it seems such a shame to give up so easily. You'd rather I wouldn’t talk about it, wouldn't you? Alright, I won't.

[Parry pats Helen's hand and begins to whistle]

Later, Parry "persuades" Helen to see a specialist in Boston. He relentlessly retells the story of her parents' death, despite the severe distress it is causing her. As Helen lies sobbing on a chair, Parry justifies his behavior as being for her own good, and then continues his bullying:

Parry: I'm sorry Helen, but I had to do it. It's only because I wanted to help you. Go over everything that happened that day, have the courage to see it all again and by not blocking out of your mind you may find your voice again $[\ldots]$

[Parry grabs Helen's arms and pulls her up to face him] Look at me! Look at me! You remember how wonderful it was when you had a voice, when you could say "hello" and "thank you"? When you could yell back at someone who started picking at you? I do it all the time. You look at me as though you don't believe it, but I know I'm right!

[He starts to shake her] 
Try to talk! Try it! Try it!

After each of these episodes, Helen seems immediately more concerned about her muteness: following the carriage ride we see her fruitlessly trying to speak to her reflection in the mirror; and after the second scene where Parry tries to force her to speak, Helen fantasizes about her wedding to the doctor. This fantasy is shown as a subjective dream sequence, where Helen shuts her eyes and the image dissolves to show her in formal eveningwear, waltzing around the entrance hall of the Warren house with Parry. The sequence dissolves again to show Helen descending the stairs dressed as a bride. The ceremony progresses but the fantasy breaks down because she cannot speak to say "I do." We cut back to the present where Helen looks confused and distressed.

This fantasy sequence marks the moment in the film where Helen is unequivocally shown to view her muteness as a problem and barrier to her relationship with Parry, whose rough treatment of her in the previous scene underlines the connection between medical discourse and Helen's positioning as a victim. Helen occupies the intertwined positions of romantic lead and fetishized victim simultaneously: both Parry and the killer are obsessed with curing Helen's muteness in order to possess her. The doctor seeks to cure her medically to take her as his wife, and the killer views his desire to possess Helen through murder as one that will also bring about her cure. Helen's acceptance of the doctor's opinion of her muteness is used to justify Parry's unpleasant behavior in the previous scene, and it is also effectively what justifies her temporary ownership of the narrative in the wedding fantasy sequence. Instead of emphasizing Helen's subjectivity in a positive and agent way, this scene actually serves primarily to reinforce her victimization. It highlights the ways in which her muteness marks her as victim, and the increasingly subservient role she occupies as Parry's love interest. Helen's stressed subjectivity is therefore one that by now emphasizes primarily her own "lack" and containment. The love theme provides the primary basis for the waltz- 
style scoring of the dream sequence, with chromatic tremolo strings giving an indication of the scene's surreal nature. Again, the love theme acts as the musical site of engagement for both the agent and contained elements of Helen's presentation, emphasizing her subjectivity through the presence of the love theme within her fantasy, but also reminding us of her victimization through the strong connections this thematic material has to both the killer's motif and the problematic figure of Dr. Parry.

The Spiral Staircase tempers Helen's feisty resourcefulness and determination (which bring to mind the survive-at-any-cost "Final Girls" of Carol Clover's work on the slasher film) by using her survival to validate Parry's diagnosis of her muteness as a psychological problem. ${ }^{48}$ Mrs. Warren's shooting of Albert triggers the sudden restoration of Helen's voice: firstly to scream, and then immediately to phone Parry for assistance, reinforcing her victimhood at the very moment when the greatest threat to her safety has been neutralized. The return of Helen's voice may be supposed to signal her shift into the role of romantic heroine and future wife, but Parry's subscription to the medical discourse that explicitly marks Helen as a victim (positioning her muteness as both lack and motivation for murder) undermines this attempt at a typical Hollywood happy ending.

Both Experiment Perilous and The Spiral Staircase demonstrate the significance of the soundtrack in constructing and communicating the gendered characterizations and relationships at the heart of the female gothic narrative. Through its engagement with the experience of the dominant medical figures of Bailey and Parry, music emphasizes the ways in which Allida and Helen are subject to the romantic and professional authority of the doctor: cues that might initially appear to be associated with the subjective experience of these women actually function to extend and codify their objectification and control at the hands of men. Dr. Bailey's control of the narrative is emphasized through the use of

\footnotetext{
${ }^{48}$ Carol Clover, "Her Body, Himself: Gender in the Slasher Film," Representations 20 (1987): 187-228.
} 
voiceover narration and subjective sound, mediating our access to the stories of both Allida and Cissie and providing a model of intellectual manliness against which Nick falls woefully short. In The Spiral Staircase, Helen's victimization is stressed by the association of her and Parry's love theme with the doctor's bullying refusal to accept her muteness, a viewpoint that is strongly (and musically) connected with the feminized madman who is stalking her.

The soundtracks of Experiment Perilous and The Spiral Staircase do not sound unusual; they sit within the stylistic and structural models of the classical Hollywood score, and within the particular generic conventions associated with film noir and the woman's film, as well as the more specific category of the female gothic. However, when considered alongside the extra-musical aspects of the female gothic narrative, particularly its reliance on medical discourse, these conventional aspects of the soundtrack are overlaid with a layer of ideological significance that makes clear their contribution to this genre's problematic constructions of gendered and sexual identity. The role of music and sound in constructing and communicating subjectivity is a crucial and complex one, placing the soundtrack in a mutually affective relationship with the other elements of a multimedia, multilayered film narrative whose whole is much more than the sum of its parts. "Meaning" and effect are reliant not just on sonic styles, structures, and events, but their relationship with other cinematic devices and their reception by a broad and largely unspecialized audience, all of whom bring their own subjectivities into play in their engagement with the film. ${ }^{49}$

Film music scholarship often cites the (disputed) maxim that classical scoring is in some way subordinate to other elements of the narrative (at least partially because of the usual place of film sound in the chronology of production), but music affects the way in

\footnotetext{
${ }^{49}$ I have deliberately sidelined this factor in order to concentrate upon the function and effect of the soundtrack within the film itself, but alternate or resistant readings of all the cues discussed are at least a theoretical possibility, despite the (often heavy-handed) efforts of classical Hollywood to direct spectator response.
} 
which these other narrative components function or are perceived, leading to a circular relationship that can often be challenging and somewhat subjective in itself to unravel. Establishing "ownership" of music and sound is contextually dependent, and can dramatically affect the way in which the soundtrack engages with issues of character subjectivitysomething that is perhaps especially obvious in music associated with female characters, whose agency in classical cinema is often limited in some way. And this means that music carries an especially heavy load of signification in the female gothic film: a genre imbued with suspenseful subjectivity and questions about the nature and veracity of "knowledge," and revolving around female protagonists. Despite the overall pessimism of my readings of Experiment Perilous and The Spiral Staircase, both films demonstrate the ways in which this contextually dependent model of ownership helps to articulate moments of greater agency for female characters. Once Bailey's flashback has ended, Allida is finally able to take or share control of "her" music in the epilogue scene, and Helen's cheery resourcefulness and strategic survival skills are heralded in her initial joint ownership of the love theme-offering at least a glimmer of hope that she might give Dr. Parry a taste of his own medicine at some point in their future relationship.

Although paling in comparison to the professional and romantic influence of the doctor, these musically facilitated moments of female agency underline the potential of classical scoring to act as a responsive and flexible element of the cinematic experience. The soundtrack's expressive potential is both intensified and contained by its textual contingency, highlighting its usefulness as a device to indicate control and subjectivity, but also meaning that other elements of cinematic narrative can radically affect the signification of even the most traditionally constructed leitmotivic scores. Given the female gothic film's dependency on personal experience and questions of reliability, these films may demonstrate the interlinked relationships between music, sound, and representation with particular clarity, but 
the impact of sonic and vocal articulations of character subjectivity upon issues of narrativity, authorship, and identity politics can be felt throughout classical Hollywood. Acting alongside misogynist medical discourse, the female gothic soundtrack helps to ensure that these filmssupposedly for and about women — are actually ones that function primarily to reinforce problematic and prescriptive constructions of gender: both femininity and non-normative masculinity are subordinate to the controlling eyes and ears of the dashing, and dangerous, doctor.

\section{References}

Barefoot, Guy. Gaslight Melodrama: From Victorian London to 1940s Hollywood. New York: Continuum, 2001.

Buhler, James. "Gender, Sexuality, and the Soundtrack," in The Oxford Handbook of Film Music Studies, ed. David Neumeyer, 366-82. Oxford: Oxford University Press, 2014.

Chion, Michel. The Voice in Cinema, trans. Claudia Gorbman. New York: Columbia University Press, 1999.

Clover, Carol. "Her Body, Himself: Gender in the Slasher Film," Representations 20 (1987): $187-228$.

Crowther, Bosley. "The Spiral Staircase,” New York Times, 7 February 1946.

Doane, Mary Ann. "Ideology and the Practice of Sound Editing and Mixing," in The Cinematic Apparatus, ed. Teresa de Lauretis and Stephen Heath, 47-56. Milwaukee, WI: MacMillan, 1980.

_. "The Clinical Eye: Medical Discourses in the 'Woman's Film' of the 1940s," Poetics Today 6/1-2 (1985): 205-27.

- The Desire to Desire: The Woman's Film of the 1940s. Bloomington: Indiana University Press, 1987.

van Elferen, Isabella. Gothic Music: The Sounds of the Uncanny. Cardiff: University of Wales Press, 2012.

Elsaesser, Thomas. "Mirror, Muse, Medusa: Experiment Perilous," Senses of Cinema 18 (2002), http://sensesofcinema.com/2001/18/perilous/.

Franklin, Peter. Seeing through Music: Gender and Modernism in Classic Hollywood Film Scores. Oxford: Oxford University Press, 2011.

Gabbard, Krin, and Glen O. Gabbard. Psychiatry and the Cinema. Chicago: University of Chicago Press, 1987.

Glinsky, Albert. Theremin: Ether Music and Espionage. Urbana: University of Illinois Press, 2000.

Gorbman, Claudia. Unheard Melodies: Narrative Film Music. London: BFI Publishing, 1987. 
Hamilton, Patrick. Gas Light: A Victorian Thriller in Three Acts. London: Constable, 1939. Hanson, Helen. "From Suspicion (1941) to Deceived (1991): Gothic Continuities, Feminism and Postfeminism in the Neo-Gothic Film," Gothic Studies 9/2 (2007): 20-32.

. Hollywood Heroines: Women in Film Noir and the Female Gothic Film. London: I.

B. Tauris, 2007.

. "The Ambience of Film Noir: Soundscapes, Design, and Mood," in A Companion to Film Noir, ed. Andrew Spicer and Helen Hanson, 285-301. Chichester: John Wiley and Sons, 2013.

Jancovich, Mark. "Crack-Up: Psychological Realism, Generic Transformation and the Demise of the Paranoid Woman's Film," Irish Journal of Gothic and Horror Studies 3 (2007). http://irishgothichorrorjournal.homestead.com/Crack-upJancovich.html.

Knight, Stephen. Crime Fiction, 1800-2000: Detection, Death, Diversity. Basingstoke: Palgrave Macmillan, 2004.

Kozloff, Sarah. Invisible Storytellers: Voice-over Narration in American Fiction Film. Berkeley, Los Angeles and London: University of California Press, 1988.

Krutnik, Frank. In a Lonely Street: Film Noir, Genre, Masculinity. London: Routledge, 1991. Laing, Heather. The Gendered Score: Music in 1940s Melodrama and the Woman's Film. Aldershot: Ashgate, 2007.

Larson, Randall D. "The Quiet Horror Music of Roy Webb: Scoring Val Lewton (the Jacques Tourneur Films)," Midnight Marquee 40 (1990): 14-17.

Lawrence, Amy. Echo and Narcissus: Women's Voices in Classical Hollywood Cinema. Berkeley: University of California Press, 1991.

Leitch, Thomas. Crime Films. New York: Cambridge University Press, 2002.

Modleski, Tania. Loving with a Vengeance: Mass-Produced Fantasies for Women. 2nd ed. New York: Routledge, 2008.

Naremore, James. More Than Night: Film Noir in Its Contexts. Berkeley: University of California Press, 1998.

Neale, Steve. "Melo Talk: On the Meaning and the Use of the Term 'Melodrama' in the American Trade Press," Velvet Light Trap 32 (1993): 66-89.

- Genre and Hollywood. London: Routledge, 2000.

Ness, Richard R. "A Lotta Night Music: The Sound of Film Noir," Cinema Journal 47/2 (2008): 52-73.

Neumeyer, David, and Nathan Platte. Franz Waxman's Rebecca: A Film Score Guide. Lanham, MD: Scarecrow Press, 2012.

Palmer, Christopher. The Composer in Hollywood. London: Marion Boyars, 1990.

Santos, Marlisa. The Dark Mirror: Psychiatry and Film Noir. Lanham, MD: Lexington Books, 2011.

Shortland, Michael. "Screen Memories: Towards a History of Psychiatry and Psychoanalysis in the Movies," The British Journal for the History of Science 20/4 (1987): 421-52.

Silverman, Kaja. The Acoustic Mirror: The Female Voice in Psychoanalysis and Cinema. Bloomington: Indiana University Press, 1988.

Smith, Andrew, and Diana Wallace. "The Female Gothic: Then and Now," Gothic Studies 6/1 (2004): 1-7. 
Snelson, Tim. “"From Grade B Thrillers to Deluxe Chillers': Prestige Horror, Female Audiences, and Allegories of Spectatorship in The Spiral Staircase (1946)," New Review of Film and Television Studies 7/2 (2009): 173-88.

Stilwell, Robynn. "Sound and Empathy: Subjectivity, Gender and the Cinematic Soundscape," in Film Music: Critical Approaches, ed. Kevin Donnelly, 167-87. New York: Continuum, 2001.

T. M. P. "At the Palace,” New York Times, 30 December 1944.

Waldman, Diane. "“At Last I Can Tell It to Someone!': Feminine Point of View and Subjectivity in the Gothic Romance Film of the 1940s," Cinema Journal 23/2 (1984): 29-40.

Walker, Janet. "Hollywood, Freud and the Representation of Women: Regulation and Contradiction, 1945-Early 1960s," in Home Is Where the Heart Is: Studies in Melodrama and the Woman's Film, ed. Christine Gledhill, 197-214. London: British Film Institute, 1987.

Walsh, Andrea S. Women's Film and Female Experience 1940-1950. New York: Praeger, 1984.

Webb, Roy. "Piano Conductor's Score for The Spiral Staircase." Special Collections Research Center, Syracuse University Library Christopher Palmer Collection of Roy Webb Scores, Oversize 13.

White, Ethel Lina. Some Must Watch. London: Ward, Lock, \& Co., 1933.

Wierzbicki, James. "Weird Vibrations: How the Theremin Gave Musical Voice to Hollywood's Extraterrestrial 'Others,'” Journal of Popular Film and Television 30/3 (2002): 125-35.

Winters, Ben. "The Non-diegetic Fallacy: Film, Music, and Narrative Space," Music \& Letters 91/2 (2010): 224-44.

\section{Filmography}

Experiment Perilous. Dir. Jacques Tourneur; comp. Roy Webb. RKO Radio Pictures, 1944. Dark Victory. Dir. Edmund Goulding; comp. Max Steiner. Warner Bros., 1939.

Gaslight. Dir. Thorald Dickinson; comp. Richard Addinsell. Anglo-American Film Corporation, 1940.

Gaslight. Dir. George Cukor; comp. Bronislau Kaper. Metro-Goldwyn-Mayer, 1944.

The Locket. Dir. John Brahm; comp. Roy Webb. RKO Radio Pictures, 1946.

The Lost Weekend. Dir. Billy Wilder; comp. Miklós Rózsa. Paramount Pictures, 1945.

Rebecca. Dir. Alfred Hitchcock; comp. Franz Waxman. Selznick International Pictures, 1940.

The Sands of Dee. Dir. D. W. Griffith. Biograph Company, 1912.

Spellbound. Dir. Alfred Hitchcock; comp. Miklós Rózsa. Vanguard Films; Selznick International Pictures, 1945.

Suspicion. Dir. Alfred Hitchcock; comp. Franz Waxman. RKO Radio Pictures, 1941. The Spiral Staircase. Dir. Robert Siodmak; comp. Roy Webb. RKO Radio Pictures; Dore Schary Productions; Vanguard Films, 1946. 
